\title{
Studies with the haeme oxygenase inhibitor Sn- protoporphyrin in patients with primary biliary cirrhosis and idiopathic haemochromatosis
}

\author{
L Berglund, B Angelin, R Hultcrantz, K Einarsson, L Emtestam, G Drummond, A Kappas
}

\begin{abstract}
$\operatorname{Sn}\left(\operatorname{tin}^{4+}\right)$-protoporphyrin, a potent competitive inhibitor of haeme oxygenase, the rate limiting enzyme in the degradation of haeme to bile pigments, was given intravenously to six patients with primary biliary cirrhosis and to four patients with idiopathic haemochromatosis. Serum bilirubin concentrations decreased in all patients after administration of 1-2 $\mu \mathrm{mol} / \mathrm{kg}$ body weight of the metalloporphyrin, given in two doses eight to 24 hours apart. This reduction lasted approximately four to five days after injection of the compound. Excretion of endogenous haeme in bile increased (mean increase approximately two to threefold) in parallel with the decrease in serum bilirubin concentrations in both patient groups, and the highest biliary haeme concentrations were found during the first $\mathbf{4 8}$ hours after treatment. Sn-protoporphyrin was cleared rapidly from plasma with a half-life of 3.4 hours. Biliary bilirubin concentrations decreased (mean decrease, 49\%) in the haemochromatosis patients after Snprotoporphyrin administration. No decrease in biliary bilirubin concentrations could be detected in the primary biliary cirrhosis patients under the same conditions. Thus, Snprotoporphyrin treatment resulted in a decrease in serum bilirubin concentrations and an increase in biliary haeme excretion in patients with haemochromatosis and primary biliary cirrhosis, as has previously been shown in normal subjects. The results indicate that the synthetic haeme analogue inhibits haeme oxidation activity in the two patient groups studied, as it does in normal people and in experimental animals. The lack of effect of $\mathrm{Sn}$ protoporphyrin on biliary bilirubin excretion in primary biliary cirrhosis may be related to a differently affected hepatic clearance system or to a different distribution of tissue bilirubin pools in this condition.
\end{abstract}

Sn-protoporphyrin is a potent competitive inhibitor of haeme oxygenase, ${ }^{1-4}$ the rate limiting enzyme in the degradation of haeme to bile pigments. ${ }^{5}$ The ability of this compound to suppress neonatal jaundice as well as several forms of naturally occurring and experimentally induced jaundice in animals has been extensively documented. ${ }^{26-11}$ It has also been found that administration of the synthetic metalloporphyrin increases the excretion of biliary haeme in animals. ${ }^{12}$ All of these properties are of potential clinical interest and have stimulated further studies on the effects of Sn-protoporphyrin in humans. We recently showed that Snprotoporphyrin caused a significant decrease in serum bilirubin as well as biliary bilirubin concentrations in healthy normal subjects. ${ }^{13}$ In addition, the metalloporphyrin was found to inhibit human liver microsomal haeme oxygenase activity in vitro and to enhance biliary haeme excretion. ${ }^{13}$ Thus, these results extend our earlier findings in experimental animals ${ }^{1+6-12}$ to normal healthy humans and establish clearly that Sn-protoporphyrin inhibits the rate of haeme degradation to bile pigments in man.

Initial studies in patients with jaundice caused by liver dysfunction or immaturity in hepatic bilirubin conjugating activity have shown that Sn-protoporphyrin can diminish the rate of increase in plasma bilirubin concentrations in term infants with neonatal jaundice associated with ABO-incompatibility, patients with Gilbert's syndrome, and in some patients with primary biliary cirrhosis. ${ }^{1+15}$ By using $\mathrm{Sn}$ protoporphyrin to inhibit haeme oxygenase activity in vivo we have also defined the existence of a physiological mechanism for biliary excretion of endogenous undegraded haeme in humans. ${ }^{13}$ The effects of inhibition of haeme oxidation activity on biliary bilirubin concentrations have not, however, been characterised previously in patients with hepatic dysfunction.

Patients with idiopathic haemochromatosis have enhanced accumulation of hepatic iron leading to cirrhosis and increased frequency of liver malignancy. ${ }^{16}$ It would therefore be of interest if the excretion of haeme, and consequently the central iron atom of haeme, from the liver could be enhanced by giving Sn-protoporphyrin to these patients. In the present report, therefore, we have carried out studies in patients with primary biliary cirrhosis and idiopathic haemochromatosis and investigated the effects of Sn-protoporphyrin in these subjects.

\section{Materials and methods}

SUBJECTS

Six patients with primary biliary cirrhosis (five women and one man) and four patients with 
TABLE I Basal clinical data on the patients studied

\begin{tabular}{|c|c|c|c|c|c|c|c|c|c|c|c|c|c|c|}
\hline $\begin{array}{l}\text { Patient } \\
\text { no }\end{array}$ & Sex & $\begin{array}{l}\text { Age } \\
\text { (yrs) }\end{array}$ & $\begin{array}{l}\text { Weight } \\
(\mathrm{kg})\end{array}$ & $\begin{array}{l}R B W \\
(\%)\end{array}$ & $\begin{array}{l}\text { Bilirubin } \\
(\mu \mathrm{mol} / \mathrm{l})\end{array}$ & $\begin{array}{l}\text { ALAT } \\
(\mu k a t / l)\end{array}$ & $\begin{array}{l}A L P \\
(\mu k a t / l)\end{array}$ & $\begin{array}{l}\text { Albumin } \\
(\mathrm{g} / \mathrm{l})\end{array}$ & $\begin{array}{l}\text { Prothrombin } \\
\text { index }(\%)\end{array}$ & $\underset{(g / l)}{I g M}$ & $A M A$ & $\begin{array}{l}\text { Serum iron } \\
(\mu \mathrm{mol} / \mathrm{l})\end{array}$ & $\begin{array}{l}\text { Serum ferritin } \\
(\mu g / l)\end{array}$ & $\begin{array}{l}\text { Clinical } \\
\text { remarks }\end{array}$ \\
\hline \multicolumn{15}{|c|}{ Patients with primary biliary cirrhosis: } \\
\hline $\begin{array}{l}1 \\
2\end{array}$ & $\mathrm{~F}$ & $\begin{array}{l}70 \\
41\end{array}$ & $\begin{array}{l}56 \\
92\end{array}$ & $\begin{array}{r}89 \\
121\end{array}$ & $\begin{array}{l}19 \cdot 2 \\
51 \cdot 8\end{array}$ & $\begin{array}{l}0.51 \\
1.78\end{array}$ & $\begin{array}{l}19 \cdot 9 \\
11 \cdot 1\end{array}$ & $\begin{array}{l}24 \\
40\end{array}$ & $\begin{array}{l}115 \\
108\end{array}$ & $\begin{array}{l}4 \cdot 1 \\
4 \cdot 1\end{array}$ & $\begin{array}{l}+ \\
+\end{array}$ & $\begin{array}{l}10 \\
27\end{array}$ & $\begin{array}{r}22 \\
166\end{array}$ & \multirow{2}{*}{$\begin{array}{l}\text { Disease } 16 \text { yrs } \\
\text { Disease } 6 \text { yrs } \\
\text { Mild diabetes } \\
\text { Disease } 4 \text { yrs } \\
\text { Disease } 4 \text { yrs } \\
\text { Disease } 3 \text { yrs } \\
\text { Disease } 6 \text { yrs }\end{array}$} \\
\hline $\begin{array}{l}3 \\
4 \\
5 \\
6\end{array}$ & $\begin{array}{l}F \\
F \\
F \\
F\end{array}$ & $\begin{array}{l}50 \\
42 \\
70 \\
56\end{array}$ & $\begin{array}{l}68 \\
78 \\
54 \\
55\end{array}$ & $\begin{array}{r}119 \\
115 \\
86 \\
87\end{array}$ & $\begin{array}{r}9 \cdot 6 \\
11 \cdot 0 \\
8 \cdot 8 \\
5.6\end{array}$ & $\begin{array}{l}1.37 \\
0.80 \\
0.99 \\
0.68\end{array}$ & $\begin{array}{r}5 \cdot 9 \\
9 \cdot 6 \\
19 \cdot 7 \\
8 \cdot 0\end{array}$ & $\begin{array}{l}39 \\
40 \\
36 \\
35\end{array}$ & $\begin{array}{l}120 \\
155 \\
140 \\
170\end{array}$ & $\begin{array}{l}3 \cdot 8 \\
6 \cdot 2 \\
3 \cdot 3 \\
3 \cdot 9\end{array}$ & $\begin{array}{l}+ \\
+ \\
+ \\
+\end{array}$ & $\begin{array}{l}14 \\
17 \\
23 \\
14\end{array}$ & $\begin{array}{r}51 \\
42 \\
190 \\
65\end{array}$ & \\
\hline \multicolumn{15}{|c|}{ Patient with alcoholic cirrhosis and hypersplenism: } \\
\hline 7 & $\mathrm{~F}$ & 64 & 99 & 168 & $19 \cdot 2$ & $0 \cdot 47$ & $2 \cdot 9$ & 37 & 80 & $1 \cdot 2$ & N.D. & 9 & 12 & $\begin{array}{l}\text { Disease } 3 \text { yrs } \\
\text { Haemolysis } \\
\text { Diabetes } \\
\text { (insulin) }\end{array}$ \\
\hline \multicolumn{15}{|c|}{ Patients with idiopathic haemochromatosis: } \\
\hline 8 & M & 59 & 83 & 114 & $23 \cdot 3$ & 0.81 & $2 \cdot 3$ & 47 & 85 & $0 \cdot 3$ & N.D. & 50 & 720 & Disease 7 yrs \\
\hline 9 & $\mathrm{~F}$ & 66 & 59 & 100 & $7 \cdot 3$ & 0.76 & 2.9 & 37 & 130 & $1 \cdot 0$ & N.D. & 50 & 1230 & Disease $1 \mathrm{yr}$ \\
\hline 10 & M & 37 & 65 & 85 & $9 \cdot 2$ & $1 \cdot 27$ & $3 \cdot 3$ & 47 & 130 & $1 \cdot 0$ & N.D. & 41 & 910 & Disease 2 yrs \\
\hline 11 & $\mathbf{M}$ & 24 & 85 & 102 & $8 \cdot 4$ & 0.89 & $2 \cdot 4$ & 45 & 120 & 0.6 & N.D. & 37 & 350 & Disease 3 yrs \\
\hline
\end{tabular}

The normal range at the Department of Clinical Chemistry, Huddinge University Hospital for serum iron is 9-38 $\mu \mathrm{mol} / \mathrm{l}$, for serum ferritin $<220 \mu \mathrm{g} / \mathrm{l}$, for serum bilirubin $<26 \mu \mathrm{mol} / \mathrm{l}$, for ALAT (alanine aminotransferase) $<0 \cdot 70 \mu \mathrm{kat} / \mathrm{l}$, ALP (alkaline phosphatase) $<4 \cdot 7 \mu \mathrm{kat} / 1$, albumin $35-46 \mathrm{~g} / \mathrm{l}$, prothrombin index $>70 \%$, IgM $0 \cdot 3-2 \cdot 0 \mathrm{~g} / \mathrm{l}$. AMA denotes antimitochondrial antibodies. RBW represents relative body weight, calculated as Weight $(\mathrm{kg}) \times 100 \%$

Height $(\mathrm{cm})-100$

untreated idiopathic haemochromatosis (three men and one woman) participated in the study. In addition, one patient with hypersplenism and haemolytic anaemia as well as alcoholic cirrhosis of the liver took part in the study. The clinical data of the patients are summarised in Table I. The diagnosis of primary biliary cirrhosis was based on clinical and laboratory evidence as well as on histological studies of percutaneous liver biopsy specimens. ${ }^{17}{ }^{18}$ For the haemochromatosis patients, no other cause for the disease, such as repeated blood transfusions or dietary factors, was present. In addition to clinical and laboratory evidence for the disease, percutaneous liver biopsy specimens taken from all patients showed appreciably increased hepatic iron content. ${ }^{1920}$ The histological examination of the samples also showed that in two of the patients with primary biliary cirrhosis (patients 1 and 5) the observed lesions were advanced. In the other four patients with primary biliary cirrhosis as well as in the four patients with haemochromatosis, however, the histological findings were compatible with an early stage of disease.

All patients were in a metabolic ward in hospital during the study and were kept on a standardised diet. ${ }^{13}$ Before Sn-protoporphyrin treatment they were subjected to ultraviolet light testing and this procedure was repeated at the end of the study. As reported elsewhere, ultraviolet light threshold values decreased immediately after administration of the metalloporphyrin $^{1521}$ but these values quickly reverted to normal in all patients after the end of the studies. Before the study the patients underwent an extensive series of clinical and biochemical tests which were repeated after the study. On both occasions only the parameters associated with the diseases deviated from normal. None of the patients were under medication for their respective diseases during the study. The study was approved by the Ethical Committee of Karolinska Institute, Huddinge University Hospital, the Clinical Trial Department of the Swedish Drug Agency (Socialstyrelsens Läkemedelsavdelning), and the Rockefeller University Institutional Review Board. Informed consent was obtained from all participants.
DESIGN OF THE STUDY

The protocol was designed as a two week study requiring serum as well as bile sampling; it has been described in detail previously. ${ }^{13}$ Briefly, fasting blood samples were drawn each morning, and in most cases additional blood samples were drawn at $4 \mathrm{pm}$ each day. In some cases, more frequent blood samples were drawn in connection with administration of the metalloporphyrin. The bile sampling procedure was carried out exactly as outlined earlier. ${ }^{13}$ One of the patients (patient 6) was, however, unable to complete this procedure. Sn-protoporphyrin was prepared and administered under previously described conditions, ${ }^{15}$ and was infused intravenously at a dose of $0.5-1.0 \mu \mathrm{mol} / \mathrm{kg}$ body weight after which the patients were fed. A second identical infusion was administered eight to 24 hours later.

\section{METHODS}

The serum and biliary bilirubin concentrations were assayed by a similar procedure. ${ }^{22}$ For analysis of biliary lipid composition, a $1.0 \mathrm{ml}$ bile

TABLE II Mean (SE) serum bilirubin concentrations before and after $S n$-protoporphyrin $(S n P P)$ treatment

\begin{tabular}{|c|c|c|c|}
\hline \multirow{2}{*}{$\begin{array}{l}\text { Patient } \\
\text { no }\end{array}$} & \multicolumn{2}{|c|}{$\operatorname{Mean}(S E)$ serum bilirubin $(\mu \mathrm{mol} / \mathrm{l})$} & \multirow{2}{*}{$\begin{array}{l}\text { \%Change in } \\
\text { serum } \\
\text { bilirubin }\end{array}$} \\
\hline & Pre-SnPP & Post-SnPP & \\
\hline \multicolumn{4}{|c|}{ Primary biliary cirrhosis: } \\
\hline & $19 \cdot 2(1 \cdot 1)$ & $15 \cdot 5(0 \cdot 4)$ & -19 \\
\hline 2 & $51 \cdot 8(4 \cdot 6)$ & $41 \cdot 4(3 \cdot 2)$ & -20 \\
\hline 3 & $9 \cdot 6(0 \cdot 7)$ & $6 \cdot 3(0 \cdot 3)$ & -34 \\
\hline 4 & $11 \cdot 0(1 \cdot 1)$ & $5 \cdot 4(0 \cdot 3)$ & -51 \\
\hline 5 & $8 \cdot 8(0 \cdot 5)$ & $7 \cdot 6(0 \cdot 4)$ & -14 \\
\hline & $5 \cdot 6(0 \cdot 5)$ & $4 \cdot 0(0 \cdot 4)$ & -29 \\
\hline \multicolumn{4}{|c|}{ Alcoholic cirrhosis and hypersplenism: } \\
\hline & $19 \cdot 2(0 \cdot 5)$ & $16 \cdot 0(0 \cdot 5)$ & -17 \\
\hline \multicolumn{4}{|c|}{ Idiopathic haemochromatosis: } \\
\hline 8 & $23 \cdot 3(4 \cdot 3)$ & $11 \cdot 3(0 \cdot 9)$ & -52 \\
\hline 9 & $7 \cdot 3(1 \cdot 0)$ & $4.9(0.5)$ & -32 \\
\hline 10 & $9 \cdot 2(1 \cdot 5)$ & $6.9(0.5)$ & -25 \\
\hline 11 . & $8 \cdot 4(1 \cdot 3)$ & $6 \cdot 1(0 \cdot 3)$ & -27 \\
\hline Mean values: & $17 \cdot 7(3 \cdot 0)$ & $13 \cdot 8(2 \cdot 0)$ & -22 \\
\hline cirrhosis $(n=6)$ & & & \\
\hline $\begin{array}{l}\text { Idiopathic haemo } \\
\text { chromatosis } \\
(n=4)\end{array}$ & $-10 \cdot 8(1 \cdot 6)$ & $7 \cdot 3(0 \cdot 5)$ & -32 \\
\hline Controls $(n=10)^{\star}$ & $11 \cdot 0(0 \cdot 5)$ & $6.9(0 \cdot 2)$ & -38 \\
\hline
\end{tabular}

$\mathrm{SnPP}=\mathrm{Sn}$-protoporphyrin and the time period before drug treatment (Pre-SnPP) was 3 days while the period after administration of the metalloporphyrin was 4 days.

$\star$ The values for the healthy human controls are from ref ${ }^{13}$. 


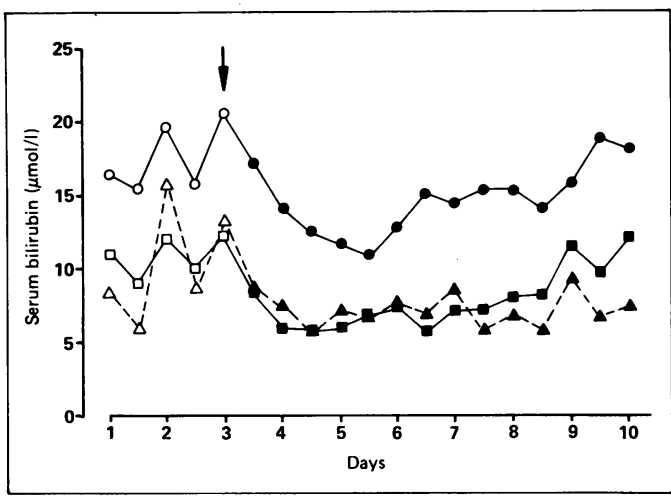

Figure 1: Effect of Sn-protoporphyrin on serum bilirubin concentrations. The values represent the mean values from six patients with primary biliary cirrhosis $(\mathrm{O}, \mathrm{O})$ and from four patients with idiopathic haemochromatosis $(\triangle, \mathbf{\Delta})$. The samples were collected in the morning $(8 \mathrm{am})$ and in the afternoon (4 pm). The morning values are given corresponding to the bar representing each day and the evening values are presented after the morning value. Open symbols represent samples before and closed symbols those after treatment with $S n$-protoporphyrin. The initial administration of $S_{n-}$ protoporphyrin is indicated by an arrow. The values for normal humans $(\square, \square)$ are given in comparison (data from $\left.r e f^{3}\right)$.

aliquot was extracted with 20 volumes of chloroform:methanol $(2: 1, v: v)$ immediately upon collection, and the chloroform phase was analysed for cholesterol ${ }^{23}$ and phospholipids. ${ }^{24}$ The total bile acid concentration was determined enzymatically. ${ }^{25}$ As described previously, in order to correct for dilution with bile and duodenal fluid, biliary bilirubin output was expressed as the ratio of bilirubin to bile acid concentration in the bile samples. ${ }^{13}$ Biliary bile acid output is not affected by administration of $\mathrm{Sn}$-protoporphyrin. Haeme was analysed after extraction from bile using the pyridine haemochromogen method $^{26}$ or in some cases by reversed phase high performance liquid chromatography. All bile samples containing haeme as judged by the pyridine haemochromogen method were extracted and analysed by thin layer chromatography. ${ }^{12}$

TABLE III Mean (SE) biliary bilirubin concentrations before and after $S n$-protoporphyrin administration

\begin{tabular}{|c|c|c|c|}
\hline \multirow{2}{*}{$\begin{array}{l}\text { Patient } \\
\text { no }\end{array}$} & \multicolumn{2}{|c|}{$\begin{array}{l}\text { Mean }(S E) \text { biliary bilirubin } \\
(\mu \text { mol/mmol bile acid })\end{array}$} & \multirow{2}{*}{$\begin{array}{l}\% \text { Change in } \\
\text { biliary } \\
\text { bilirubin }\end{array}$} \\
\hline & $\operatorname{Pre}-\operatorname{SnPP}$ & Post-SnPP & \\
\hline \multicolumn{4}{|c|}{ Primary biliary cirrhosis: } \\
\hline & $28 \cdot 5(3 \cdot 0)$ & $45 \cdot 4(2 \cdot 4)$ & +60 \\
\hline 2 & $7 \cdot 8$ & $16 \cdot 2(2 \cdot 5)$ & +108 \\
\hline 3 & $15 \cdot 6(2 \cdot 0)$ & $11 \cdot 3(0 \cdot 9)$ & -28 \\
\hline 4 & $11 \cdot 3(3 \cdot 1)$ & $11 \cdot 8(2 \cdot 5)$ & +4 \\
\hline 5 & $20 \cdot 6(2 \cdot 8)$ & $17 \cdot 6(2 \cdot 0)$ & -15 \\
\hline \multicolumn{4}{|c|}{ Alcoholic cirrhosis and hypersplenism: } \\
\hline & $4.9(0.4)$ & $4 \cdot 5(1 \cdot 2)$ & -8 \\
\hline \multicolumn{4}{|c|}{ Idiopathic haemochromatosis: } \\
\hline 8 & $23 \cdot 8(6 \cdot 2)$ & $12 \cdot 6(1 \cdot 1)$ & -47 \\
\hline 9 & $8 \cdot 5(4 \cdot 3)$ & $4 \cdot 2(0 \cdot 8)$ & -51 \\
\hline 10 & $26 \cdot 3(2 \cdot 9)$ & $9 \cdot 5(2 \cdot 3)$ & -64 \\
\hline Mean values: & $25 \cdot 7(1 \cdot 2)$ & $16 \cdot 2(1 \cdot 6)$ & -37 \\
\hline $\begin{array}{l}\text { Primary biliary } \\
\text { cirrhosis }(n=6)\end{array}$ & $15 \cdot 1(2 \cdot 3)$ & $18 \cdot 6(3 \cdot 3)$ & +22 \\
\hline $\begin{array}{l}\text { Idiopathic haemo } \\
\text { chromatosis } \\
(n=4)\end{array}$ & $-20 \cdot 7(3 \cdot 0)$ & $10 \cdot 5(1.4)$ & -49 \\
\hline Controls $(n=10)^{\star}$ & $16 \cdot 2(2 \cdot 0)$ & $8 \cdot 6(1 \cdot 2)$ & -43 \\
\hline
\end{tabular}

$\mathrm{SnPP}=\mathrm{Sn}$-protoporphyrin and the time period before drug treatment (Pre-SnPP) was in general three days ( 2 days in patient 11 and one day in patient 2), while the sampling period after the 11 and one day in patient 2), while the sampling period after the
administration of the metalloporphyrin (Post-SnPP) was 4 days (3 days in patient 1 ).

$\star$ The values for the healthy human controls are from ref $^{3}$.

\section{Results}

EFFECT OF SN-PROTOPORPHYRIN ON SERUM BILIRUBIN CONCENTRATIONS

As seen in Table I, only one patient with primary biliary cirrhosis had an increased serum bilirubin concentration before the study. After Snprotoporphyrin administration the serum bilirubin concentrations decreased in all patients studied. To quantitate the average decrease in serum bilirubin, the mean values from the period before treatment were compared with the corresponding values for a four day period immediately afterwards (Table II). The mean decrease for serum bilirubin in all patients was 3-4 $\mu \mathrm{mol} / \mathrm{l}$ (29\%) with a range of $1-12 \mu \mathrm{mol} / \mathrm{l}(14-52 \%)$. The decrease was rapid in onset and lasted for four to five days (Fig 1). Thereafter the bilirubin concentrations returned to values before treatment. The effect of Sn-protoporphyrin on serum bile pigment values was in general similar in both groups of patients to those previously reported in healthy volunteers. ${ }^{13}$

EFFECT ON SN-PROTOPORPHYRIN ON BILIARY BILIRUBIN CONCENTRATIONS

Biliary bilirubin concentrations were measured both before and after Sn-protoporphyrin administration. The basal biliary bilirubin concentration found under these conditions was similar in both patient groups and did not differ from that in healthy controls (Table III). As is evident from Figure 2, there was no net reduction in biliary bilirubin concentrations after metalloporphyrin treatment in the patient group with primary biliary cirrhosis.

In the patients with haemochromatosis there was a decrease in biliary bilirubin output after Sn-protoporphyrin administration, in agreement with our previous findings in normal humans. ${ }^{13}$ The mean decrease in biliary bilirubin in the haemochromatosis group was $49 \%(\mathrm{p}<0.005$, Student's $t$-test). No changes were found in the phospholipid and cholesterol content in the bile during the course of the study in either patient group (Table IV). The values were in close agreement with those for healthy humans. ${ }^{13}$

\section{PHARMACOKINETIC STUDIES OF} SN-PROTOPORPHYRIN

$\mathrm{Sn}$-protoporphyrin was given to each patient in two identical intravenous infusions. The plasma values of $\mathrm{Sn}$-protoporphyrin were measured after the first infusion in three of the patients to determine plasma half life. The initial peak concentration of the metalloporphyrin was $\approx 5$ $\mathrm{nmol} / \mathrm{ml}$ and the decline was log-linear with time with a plasma half life of 3.4 hours, in excellent agreement with the previous findings for healthy volunteers. ${ }^{13}$ All patients tolerated the drug well and apart from transient photosensitising effects no side effects were noted.

\section{INFLUENCE OF SN-PROTOPORPHYRIN ON HAEME} VALUES IN BILE

In three of the patients with haemochromatosis and in some with primary biliary cirrhosis there 


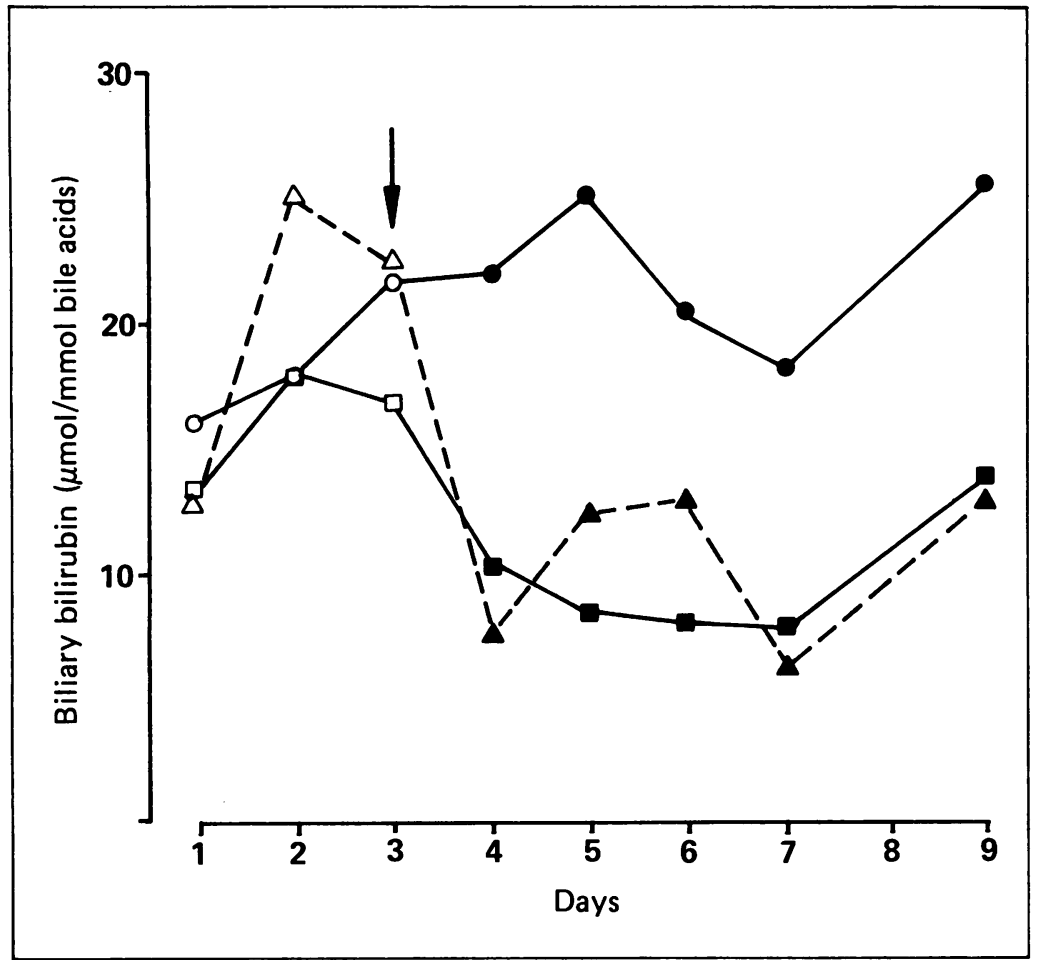

Figure 2: The effect of Sn-protoporphyrin administration on bilirubin concentrations in bile. The values are expressed as the bilirubin:bile acid ratio as outlined in the text. Mean values from six patients with cirrhosis $(O, \mathbf{O})$ and four patients with haemochromatosis $(\triangle, \mathbf{\Delta})$ are given. For comparison, the values for healthy volunteers are included in the figure $(\square, \mathbf{\square})$, data from ref ${ }^{3}$. Open symbols show values before and closed symbols values after $S n$-protoporphyrin administration. The initial administration of the metalloporphyrin is indicated by the arrow.

were detectable amounts of haeme in the bile before metalloporphyrin treatment (Table V). The values in the haemochromatosis group were, however, slightly higher than those in the primary biliary cirrhosis group and those previously reported for normal subjects. ${ }^{13}$ After administration of Sn-protoporphyrin, biliary haeme values increased in all four patients with haemochromatosis and in the five subjects with primary biliary cirrhosis. As seen in Table V, the mean increase was found to be approximately threefold. In one of the subjects, patient 7, biliary haeme concentrations were very high $(\approx 49-58 \mu \mathrm{mol} / \mathrm{l})$ throughout the study and did not change after $\mathrm{Sn}$-protoporphyrin treatment. In addition to cirrhosis of the liver, this patient suffered from haemolytic anaemia and had an enlarged spleen. Thus, the clinical findings of accelerated haemoglobin breakdown in this patient correlated well with the increased biliary excretion of haeme. In all other patients the highest haeme concentrations were found during the first 48 hours after Sn-protoporphyrin

TABLE IV Mean (SE) biliary cholesterol and phospholipid values

\begin{tabular}{llllll}
\hline & \multicolumn{2}{l}{$\begin{array}{l}\text { Biliary cholesterol } \\
(\text { mmol/mmol bile acid })\end{array}$} & & \multicolumn{2}{l}{$\begin{array}{l}\text { Biliary phospholipids } \\
\text { (mmol/mmol bile acid })\end{array}$} \\
\cline { 2 - 3 } $\begin{array}{l}\text { Patient } \\
\text { group }\end{array}$ & Pre-SnPP & Post-SnPP & & Pre-SnPP & Post-SnPP \\
\hline $\begin{array}{l}\text { Primary biliary } \\
\text { cirrhosis: }(\mathrm{n}=7) \\
\begin{array}{c}\text { Haemochromatosis } \\
(\mathrm{n}=4)\end{array}\end{array}$ & $0.10(0.01)$ & $0.10(0.01)$ & & $0.33(0.02)$ & $0.28(0.02)$ \\
\hline
\end{tabular}

$\mathrm{SnPP}=\mathrm{Sn}$-protoporphyrin and the time period before drug treatment (Pre-SnPP) was in general 3 days while the sampling period after administration of the metalloporphyrin (Post-SnPP) was 4 days
Patient 7 , who had an alcoholic cirrhosis of the liver, was included in the primary biliary cirrhosis group as the data from this patient did not differ from the other patients in the cirrhosis group.
TABLE V Effect of Sn-protoporphyrin on biliary haeme excretion

\begin{tabular}{|c|c|c|c|}
\hline \multirow{2}{*}{$\begin{array}{l}\text { Patient } \\
\text { no }\end{array}$} & \multicolumn{2}{|c|}{ Biliary haeme $(\mu \mathrm{mol} / \mathrm{l})$} & \multirow{2}{*}{$\begin{array}{l}\% \text { Increase in } \\
\text { biliary haeme }\end{array}$} \\
\hline & Pre-SnPP & Post-SnPP & \\
\hline \multicolumn{4}{|c|}{ Primary biliary cirrhosis: } \\
\hline 1 & $10 \cdot 1$ & $13 \cdot 0$ & 29 \\
\hline 2 & ND & $2 \cdot 3$ & $\star$ \\
\hline 3 & $2 \cdot 6$ & $7 \cdot 1$ & 273 \\
\hline 4 & ND & $17 \cdot 6$ & $\star$ \\
\hline & 1.8 & $5 \cdot 1$ & 283 \\
\hline \multicolumn{4}{|c|}{ Alcoholic cirrhosis and hypersplenism: } \\
\hline & 58.0 & $49 \cdot 0$ & -16 \\
\hline \multicolumn{4}{|c|}{ Idiopathic haemochromatosis: } \\
\hline 8 & $6 \cdot 0$ & $12 \cdot 2$ & 102 \\
\hline 9 & $5 \cdot 6$ & $5 \cdot 8$ & 4 \\
\hline 10 & $5 \cdot 3$ & $34 \cdot 3$ & 545 \\
\hline 11 & ND & $2 \cdot 4$ & ^ \\
\hline \multicolumn{4}{|l|}{ Mean values: } \\
\hline $\begin{array}{l}\text { Primary biliary } \\
\text { cirrhosis }\end{array}$ & $2 \cdot 9$ & $9 \cdot 0$ & 310 \\
\hline $\begin{array}{l}\text { Idiopathic haemo- } \\
\text { chromatosis }\end{array}$ & $4 \cdot 2$ & $13 \cdot 7$ & 223 \\
\hline
\end{tabular}

The numbers represent mean values from biliary samples taken either before (Pre-SnPP) or after (Post-SnPP) administration of Sn-protoporphyrin (SnPP). The variation between day to day samples in each patient was in general substantial and the numbers given represent mean daily values for each period. The sampling given represent mean daily values for each period. The sampling
period before drug treatment was in general 3 days, while the period before drug treatment was in general 3 days, while the
period after administration of the metalloporphyrin was 4 days. In three of the patients $(2,4$, and 11$)$, no haeme could be detected in the bile samples before the treatment, and it was thus not possible to calculate the relative increase in biliary haeme values which is indicated by the asterisk. Patient 7 suffered from haemolytic anaemia in addition to cirrhosis of the liver and was therefore excluded when calculating mean values.

$\mathrm{ND}=$ not detectable. The detection limit of haeme in the assay procedure used was $0.5 \mu \mathrm{mol} / \mathrm{l}$.

administration. Apart from a somewhat delayed peak in haeme excretion, the pattern correlated well with that found in normal humans. ${ }^{13}$

\section{Discussion}

We have examined the effect of Snprotoporphyrin administration in patients with primary biliary cirrhosis and idiopathic haemochromatosis on various parameters of haeme and bile pigment metabolism. There is currently no established cure for primary biliary cirrhosis nor has its aetiology been clarified. ${ }^{18}$ In advanced stages of the disease, serum bilirubin concentrations increase substantially; the patients reported here were mostly in the early stages of the disease and serum bilirubin concentrations were therefore increased to an abnormal level in only one (Table I). Serum bilirubin concentrations, however, decreased promptly in all patients after Snprotoporphyrin administration. The effect was seen within 24 hours in all subjects, the mean decrease for the group being $20 \%$ (range 14 $51 \%$ ). This value was somewhat less than the corresponding decrease observed for the haemochromatosis patients (32\%) and for a control group $(38 \%){ }^{13}$ The actual decrease in serum bilirubin was, however, similar in all groups (3-4 $\mu \mathrm{mol} / \mathrm{l})$, and the smaller relative decrease in the primary biliary cirrhosis group probably reflected a higher baseline bilirubin concentration in these patients. The findings raise the possibility that Sn-protoporphyrin or related haeme oxygenase inhibitors administered at appropriate intervals would be of value in reducing increased serum bilirubin concentrations in patients with primary biliary cirrhosis. Furthermore, the fact that serum bilirubin concentrations were also reduced in patients with haemochromatosis indicates that the metalloporphyrin is likely to be effective in 
moderating the degree of jaundice in other types of liver disease.

In contrast to the findings for serum bilirubin, the effect of Sn-protoporphyrin on biliary bilirubin concentrations differed between the two patient groups. In the haemochromatosis patients we were able to show a decrease in biliary bilirubin after Sn-protoporphyrin administration, and this response was similar to that in normal subjects. ${ }^{13}$ In the primary biliary cirrhosis patients, however, no such decrease was detected (Fig 2). There was a considerable interindividual variation in this patient group, but not even when the individual response to Sn-protoporphyrin on biliary bilirubin concentrations was studied were we able to detect a common pattern (Table III).

Although indirect measurements of hepatic function - such as prothrombin time and serum albumin - were not abnormal in the patients with primary biliary cirrhosis (Table I), it should be noted that albumin concentrations tended to be lower and bilirubin concentrations tended to be higher in this group than in the patients with haemochromatosis. Even if we consider the possibility unlikely, we cannot at present exclude the presence of a difference in liver function between the two groups.

The absence of a reduction in biliary bilirubin concentrations after $\mathrm{Sn}$-protoporphyrin administration in patients with primary biliary cirrhosis could result from several different factors, including differences in clearance of the metalloporphyrin, differences in the interaction of Snprotoporphyrin with haeme oxygenase in this disorder, variations in the tissue stores of bilirubin, or a decrease in overall bile or bile acid output. We did not find supportive evidence for any of these explanations as the clearance of Snprotoporphyrin was similar in all subjects, serum bilirubin concentrations decreased in the primary biliary cirrhosis group as it did in the haemochromatosis patients, and no reductions in other biliary compounds such as cholesterol, phospholipids, or haeme were detected. Thus, the clear difference in effect on serum and biliary bilirubin concentrations of $\mathrm{Sn}$-protoporphyrin in the primary biliary cirrhosis group compared with normal subjects and patients with haemochromatosis suggests that the hepatic clearance system for bilirubin may be affected differently in the primary biliary cirrhosis patients compared with the other groups investigated, or that patients with primary biliary cirrhosis have a larger pool of tissue bilirubin which masks an effect of metalloporphyrin on biliary bilirubin output. In this circumstance the prompt reduction in the production of bilirubin induced by $\mathrm{Sn}$-protoporphyrin would presumably take longer to affect the tissue pool, and thus the initial output of biliary bilirubin would be unchanged. Under prolonged inhibition of haeme oxidation activity, however, biliary bilirubin concentrations might be expected to be altered in primary biliary cirrhosis patients. Further studies are needed to explore the longterm effects of Sn-protoporphyrin treatment on bile pigment disposal in this patient group.

The second clinical group we studied were patients with idiopathic haemochromatosis. In these patients there is a continuous accumulation of hepatic iron as a result of increased intestinal absorption, and the increased load of iron results in hepatic malfunction. ${ }^{27}{ }^{28}$ One of the objectives of treatment with Sn-protoporphyrin in these patients was to determine if it was possible to increase the output of haeme and thus of its contained iron atom. In the present study we were able to show an increase in biliary haeme excretion in several of these patients after Snprotoporphyrin treatment, though the response was variable. The degree of increase was, however, similar to that seen in the primary biliary cirrhosis patients and also in normal volunteers. ${ }^{13}$ It has recently been shown that increased biliary secretion of iron occurs during iron overload but also that the capacity of this excretory pathway is limited. ${ }^{20}$ Thus, whether it is feasible by administering haeme oxygenase inhibitors on a longterm basis to enhance biliary haeme and in this fashion iron excretion to a sufficient extent to induce a negative iron balance in haemochromatosis remains to be determined.

We thank Ms Marlene Hedström, Ms Sabine Süllow, Mr Roland Eklöf, and Ms Tracy Pfeifer for excellent technical assistance and Ms Lena Ericsson for typing the manuscript. This project was supported by the Swedish Medical Research Council (Project No. $03 \mathrm{X}-4793$ ) and by private gifts to the Rockefeller University. The Nicholson Foundation exchange program between The provided partial support for Professor A Kappas during the course of these studies.

1 Drummond GS, Kappas A. Prevention of neonatal hyperbilirubinemia by tin protoporphyrin IX, a potent competitive inhibitor of heme oxidation. Proc Natl Acad Sci USA 1981; 78: $6466-70$.

2 Drummond GS, Kappas A. Chemoprevention of neonatal jaundice: potency of tin-protoporphyrin in an animal model. Science 1982; 217: 1250-2.

3 Drummond GS, Kappas A. Suppression of hyperbilirubinemia in the rat neonate by chromium-protoporphyrin: Interaction of metalloporphyrin with microsomal heme oxygenase of human spleen. $\mathcal{F}$ Exp Med 1982; 156: 187883.

4 Yoshinaga T, Sassa S, Kappas A. Purification and properties of bovine spleen heme oxygenase. Amino acid composition and sites of inhibitors of heme oxidation. F Biol Chem 1982;
257: 7778-85.

5 Tenhunen R, Marver HS, Schmid R. Microsomal heme oxygenase: Characterization of the enzyme. $\mathcal{F}$ Biol Chem
1969; 244: 6388-96.

6 Drummond GS, Kappas A. Sn-protoporphyrin inhibition of fetal and brain heme oxygenase: Transplacental passage of the metalloporphyrin and prenatal suppression of hyperbilirubinemia in the newborn animal. $\mathcal{F}$ Clin Invest 1986; 77 : 971-6.

7 Cornelius CE, Rodgers PA. Prevention of neonatal hyperbilirubinemia in rhesus monkeys by tin-protoporphyrin. Pediatr Res 1984 ; 18: 728-30.

8 Cornelius CE, Rodgers PA, Bruss ML, Ahlfors CE. Characterization of a Gilbert-like syndrome in squirrel monkeys (Saimiri sciureus). F Med Primatol 1985; 14: 59-74.

9 Sassa S, Drummond GS, Bernstein SE, Kappas A. Tinprotoporphyrin suppression of hyperbilirubinemia in mutant mice with severe hemolytic anemia. Blood 1983; 61: 1011-3.

10 Drummond GS, Kappas A. An experimental model of postnatal jaundice in the suckling rat: Suppression of induced hyperbilirubinemia by Sn-protoporphyrin. 7 Clin Invest 1984; 74: 142-9.

11 Kappas A, Drummond GS. Control of heme metabolism with synthetic metalloporphyrins. $\mathcal{F}$ Clin Invest 1986; 77: 335-9.

12 Kappas A, Simionatto CS, Drummond GS, Sassa S, Anderson KE. The liver excretes large amounts of heme into bile when heme oxygenase is inhibited competitively by $\mathrm{Sn}$ protoporphyrin. Proc Natl Acad Sci USA 1985; 82: 896900

13 Berglund L, Angelin B, Blomstrand R, Drummond GS, Kappas A. Sn-protoporphyrin lowers serum bilirubin levels, decreases biliary bilirubin output, enhances biliary heme activity in normal human subjects. Hepatology 1988; 8: 62531 .

14 Kappas A, Drummond GS, Manola T, Petmezaki S, Valaes T. Sn-protoporphyrin use in the management of hyperSn-protoporphyrin use in the management of hyper-
bilirubinemia in term newborns with direct Coombs-positive bilirubinemia in term newborns with direct Coombs
ABO incompatibility. Pediatrics 1988; 81: 485-97.

15 Anderson KE, Simionatto CS, Drummond GS, Kappas A. Pharmacokinetics of Sn-protoporphyrin and suppression of hyperbilirubinemia in humans. Clin Pharmacol Ther 1986; 39: $510-21$ 
16 Niederau C, Fischer R, Sonnenberg A, Stremmel W, Tampish HJ, Strohmeyer G. Survival and causes of death in cirrhotic and non cirrhotic patients with primary hemochromatosis. NEngl F Med 1985; 313: 1258-62.

17 Sherlock S, Scheuer PJ. The presentation and diagnosis of 100 patients with primary biliary cirrhosis. $N$ Engl $\Im$ Med 1973 ; patients with

18 Kaplan MM. Primary biliary cirrhosis. N Engl f Med 1987; 316: $521-8$.

19 Valberg LS, Ghent CN. Diagnosis and management of hereditary hemochromatosis. Ann Rev Med 1985; 36: 27 37.

20 Hultcrantz R, Angelin B, Björn-Rasmussen E, Ewerth S, Einarsson K. Biliary excretion of iron and ferritin in idiopathic hemochromatosis. Gastroenterology 1989; 96: $1539-45$.

21 Emtestam L, Berglund L, Angelin B, Drummond DS Kappas A. Sn-protoporphyrin and long wave length ultraviolet light in the photochemotherapy of psoriasis. Lance 1989; i: 1231-3.
22 Jendrassik L, Grof P. Vereinfachte photometrische Methoden zur Bestimmung des Blutbilirubins. Biochem Z 1938; 297 81-9.

23 Roda A, Festa D, Sama C, et al. Enzymatic determination of cholesterol in bile. Clin Chim Acta 1975; 64: 337-41.

24 Rouser G, Sidney F, Akira Y. Two dimensional thin-layer chromatography separation of polar lipis and determinations chromatography separation of polar lipis and determinatic

25 Fausa $\mathrm{O}$, Skålhegg BA. Quantitative determination of bile acids and their conjugates using thin-layer chromatography and a purified $3 \alpha$-hydroxysteroid dehydrogenase. Scand and a purified $3 \alpha$-hydroxyster.

26 Paul KG, Thorell H, Akeson A. The molar light absorption of pyridine ferroprotoporphyrin (pyridine hemochromogen). Acta Chem Scand 1953; 7: 1284-7.

27 Sheldon JH. Haemochromatosis. London: Oxford University Press, 1935.

28 Brink B, Disler P, Lynch S, Jacobs P, Charlton R, Bothwell T. Patterns of iron storage in dietary iron overload and idiopathic hemochromatosis. F Lab Clin Med 1976; 88: 725-31. 